\title{
KAJIAN PEMBERIAN PUPUK KANDANG AYAM PEDAGING DAN PUPUK HAYATI TERHADAP PERTUMBUHAN DAN HASIL PETSAI (Brassica chinensis L.)
}

\author{
Jhon Hardy Purba*, Putu Sri Wahyuni*, Irwan Febryan* \\ email: jhonhardy@yahoo.com \\ *Fakultas Pertanian Universitas Panji Sakti, Singaraja
}

\begin{abstract}
This research aims to determine the effect of broiler manure doses and BiotamaxTM biofertilizers on growth and yield of Chinese cabbage in the Selat Village, Buleleng Regency, Bali from November - December 2018. The randomized block design (RBD) factorial, consisting of two factors was the experimental design used in this research. The first factor is the dose of broiler manure (A), composed of 3 levels, namely control (AO), a dose of 15 tons.ha-1 (A1), and 30 tons.ha-1 (A2). The second factor is the application frequency of biological fertilizers with four levels, namely control (BO) which was administered concurrently for seven days before planting at a dose of 0.09 g.plots-1. B1 with an administrative frequency of 7 and 14 days before and after planting (HST), respectively, with a dose of 0.045 g.plots-1. (B2) with a 3times administrative frequency of 7 , 14, and 28 days before, after birth and after each dose of 0.03 g.plots-1 (B3). The results of the study, the frequency of giving BiotaMaxTM biological fertilizer at the same time, provided the heaviest oven-dry weight per crop, which was $9.39 \mathrm{~g}$. The treatment of broiler chicken manure dose of 30 tons.ha-1 (A2), resulted in the best oven-dry weight canopy per plant at $9.26 \mathrm{~g}$. The relationship between the dose of broiler chicken manure with canopy oven-dry weight per plant showed a linear relationship, namely y $=0.0608 x+7.2483(R 2=$ 32.53). The best economic weight per hectare is obtained in the provision of 30 tons.ha-1 (A2) broiler manure, weighing 30.10 tons.ha-1. The relationship between the dose of broiler manure and economic weight per hectare shows a linear relationship, $y=0.3247 x+21.699 R^{2}=59.88 \%$. The frequency of giving BiotaMaxTM biofertilizers at the same time is 7 days before planting at a dose of 0.09 g.plots-1 (B1) gave the heaviest economic weight per hectare, at 28.21 tons.ha-1. The combination of broiler chicken manure dose and the frequency of BiotaMaxTM biofertilizer gave no significant effect $(p \geq 0.05)$ on the growth and yield of Chinese cabbage.
\end{abstract}

Keywords: broiler manure, biofertilizer frequency, petsai

Abstrak. Penelitian yang bertujuan mengetahui pengaruh dosis pupuk kandang ayam pedaging dan pupuk hayati Biotamax ${ }^{\mathrm{TM}}$ serta interaksinya terhadap pertumbuhan dan hasil petsai dilaksanakan di Desa Selat, Kabupaten Buleleng, Bali pada bulan November - Desember 2018. Rancangan percobaan yang digunakan adalah rancangan acak kelompok (RAK) faktorial, terdiri atas dua faktor. Faktor pertama adalah dosis pupuk kandang ayam pedaging (A), terdiri atas 3 tingkat, yaitu kontrol $\left(\mathrm{A}_{0}\right)$, dosis 15 ton.ha $^{-1}\left(\mathrm{~A}_{1}\right)$, dan 30 ton.ha ${ }^{-1}$ $\left(\mathrm{A}_{2}\right)$. Faktor ke dua adalah frekuensi pemberian pupuk hayati dengan empat tingkat, yaitu kontrol $\left(\mathrm{B}_{0}\right)$, pemberian sekaligus yaitu 7 hari sebelum tanam dengan dosis 0,09 g.petak ${ }^{-1}\left(B_{1}\right)$; frekuensi pemberian 2 kali yaitu 7 hari sebelum tanam dan 14 hari sesudah tanam (hst) dengan dosis setiap pemberian 0,045 g.petak $^{-1}\left(B_{2}\right)$; frekuensi pemberian 3 kali yaitu 7 hari sebelum tanam, 14 hst dan 28 hst dengan dosis setiap pemberian 0,03 g.petak ${ }^{-1}\left(B_{3}\right)$. Hasil penelitian, frekuensi pemberian pupuk hayati BiotaMax ${ }^{\mathrm{TM}}$ sekaligus, memberikan berat kering oven tajuk per tanaman terberat, yaitu 9,39 g. Perlakuan dosis pupuk kandang ayam pedaging dosis 30 ton.ha $^{-1}\left(A_{2}\right)$, menghasilkan berat kering oven tajuk per tanaman terbaik yaitu 9,26 g. Hubungan antara dosis pupuk kandang ayam pedaging dengan berat kering oven tajuk per tanaman menunjukan hubungan linier, yaitu $y=0,0608 x+7,2483\left(R^{2}=32,53\right)$. Berat ekonomis per hektar terbaik didapatkan pada pemberian dosis pupuk kandang ayam pedaging 30 ton.ha ${ }^{-1}\left(\mathrm{~A}_{2}\right)$, yaitu seberat 30,10 ton.ha ${ }^{-1}$. Hubungan antara dosis pupuk kandang ayam pedaging dan berat ekonomis per hektar menunjukan hubungan linier, yaitu $y=0,3247 x+21,699$ $\mathrm{R}^{2}=59,88 \%$. Frekuensi pemberian pupuk hayati BiotaMax ${ }^{\mathrm{TM}}$ sekaligus yaitu 7 hari sebelum tanam dengan dosis 0,09 g.petak ${ }^{-1}\left(B_{1}\right)$ memberikan berat ekonomis per hektar terberat, yaitu 28,21 ton.ha ${ }^{-1}$. Kombinasi dosis pupuk kandang ayam pedaging dan frekuensi pemberian pupuk hayati BiotaMax ${ }^{\mathrm{TM}}$ berpengaruh tidak nyata $(\mathrm{p} \geq 0,05)$ terhadap pertumbuhan dan hasil petsai.

Kata kunci: Pupuk Kandang Ayam Pedaging, Frekuensi Pupuk hayati, Petsai.

\section{PENDAHULUAN}

Tanaman

petsai

(Brassica

chinensis L.) termasuk jenis sayuran daun yang bernilai gizi tinggi (terutama vitamin dan mineral), mempunyai nilai ekonomi tinggi untuk memenuhi permintaan pasar swalayan, restoran Eropa dan Cina, hotel serta konsumen warga negara asing yang 
menetap di Indonesia. Produksi sayuran petsai di Bali baru mancapai tingkat ratarata 12 t.ha ${ }^{-1}$. Menurut Nasaruddin (2010), pertumbuhan dan perkembangan daun pada awal pertumbuhan tanaman akan terus bertambah sejalan dengan pertambahan umur tanaman.

Produksi ini dapat dikatakan masih rendah bila dibandingkan dengan potensi ginetis yaitu rata-rata menghasilkan 20 t.ha $^{-1}$. Petsai dapat dibudidayakan pada dataran tinggi maupun dataran rendah, tetapi hampir kebanyakan tanaman petsai diusahakan di dataran tinggi, terutama jenis petsai bunga/pak choi (Rukmana, 2007).

Berbagai upaya pengembangan tanaman petsai telah dilakukan namun masih belum memenuhi permintaan pasar terutama pada bulan Juli-Agustus dan Nopember-Desember, khususnya di Denpasar dan sekitarnya. Selain karena permintaan tinggi, cara budidaya petsai yang dilakukan petani belum tepat terutama dari segi pemupukan pupuk organik maupun anorganik membuat produktivitas lahan belum optimal. Petani sudah sering memberikan pupuk organik (pupuk kandang sapi, ayam, dan jenis pupuk organik lainnya) pada setiap penanaman, namun dosisnya belum tepat. Selain itu lahan tersebut terus menerus ditanami sayuran, sehingga bahan organik didalam tanah menjadi berkurang. Hal ini ditunjukkan kandungan C-organik tanah termasuk sangat rendah $0,42 \%$ (Laboratorium Tanah Universitas Udayana, 2018).

Pupuk organik merupakan bahan pembenah tanah yang paling baik dan alami dari pada bahan pembenah buatan/sintesis. Pupuk kandang ayam merupakan sumber nitrogen tanah yang utama, serta berperan cukup besar dalam memperbaiki sifat fisik, kimia, dan biologis tanah. Di dalam tanah, pupuk organik akan dirombak oleh organisme menjadi humus atau bahan organik tanah (Hadisuwito,2007).
Dari penelitian Hanafiah (1989) menunjukkan bahwa pemberian pupuk kandang ayam setelah 8 minggu dapat memperbaiki sifat kimia tanah. Pemberian pupuk kandang selain dapat menambah tersedianya unsur hara, juga dapat mendukung pertumbuhan mikroorganisme serta mampu memperbaiki struktur tanah (Mayadewi, 2007). Salah satu mikrooranisme yang perannya sangat penting untuk memperbaiki struktur tanah adalah Azotobakter sp yang merupakan menambat nitrogen dalam tanah (Irvan, 2007). Menurut Usman (2012), udara mengandung sekitar $80 \%$ nitrogen, namun unsur $\mathrm{N}$ yang secara langsung dapat digunakan oleh tanaman hanya sedikit. Kandungan pupuk kandang yang kaya akan unsur $\mathrm{N}$ sangat sesuai dengan tanah bakal calon tempat penelitian melihat nilai kadar $\mathrm{N}$ total $0,16 \%$ (sangat rendah).

Sehingga pupuk kandang ayam akan mampu memberikan asupan pada tanah dan tanaman selain penambahan pupuk basal nantinya. Bahan organik berfungsi sebagai "pengikat" butiran primer tanah menjadi butiran sekunder dalam pembentukan agregat yang mantap. Keadaan ini berpengaruh besar pada porositas, penyimpanan dan penyediaan air serta aerasi dan temperatur tanah. Bahan organik dengan $\mathrm{C} / \mathrm{N}$ tinggi seperti jerami dan sekam memberikan pengaruh yang lebih besar pada perubahan sifat-sifat fisik tanah dibanding bahan organik yang telah terdekomposisi seperti kompos. Kandungan pupuk kandang ayam pedaging adalah sebagai berikut: $2.79 \% \mathrm{~N}, 0.52 \%$ $\mathrm{P}_{2} \mathrm{O}_{5}, 2.29 \% \mathrm{~K}_{2} \mathrm{O}$.

Pupuk organik memacu dan meningkatkan populasi mikrobia didalam tanah. Tanah yang kaya bahan organik relatif lebih sedikit hara yang terfiksasi mineral tanah, sehingga yang tersedia bagi tanaman lebih besar. Hara yang dimanfaatkan oleh mikroorganisme tanah bermanfaat dalam mempercepat aktivitasnya, meningkatkan kecepatan dekomposisi bahan organik, dan 
mempercepat pelepasan hara (Sutanto, 2002).

Untuk mendapatkan hasil yang baik perlu juga diberikan pupuk-pupuk yang dapat memepercepat pertumbuhan tanaman dan memperbesar hasil. Untuk itu dalam penelitian kali ini yang digunakan adalah Pupuk hayati Biotamax ${ }^{\mathrm{TM}}$ merupakan pupuk organik hayati yang diproduksi dengan menggunakan 10 jenis organisme seperti Bacillus subtilis, Bacillus latersporus, Bacillus licheniformus, Bacillus megaterium, Bacillus pumilus, Trichoderma harzianum, Trichoderma koningii, Trichoderma polysporum, dan Paenibacillus polymyxa. Bakteri dan jamur menguntungkan tersebut dijumpai pada tanah yang sehat dan produktif sehingga membuat pertumbuhan tanaman lebih baik dan cepat. Secara alami mengembalikan organisme tanah, berisi bakteri menguntungkan dan jamur menguntungkan yang ditemukan dalam tanah, tanah produktif yang memungkinkan untuk tumbuhnya tanaman yang lebih subur, perbaikan tanah saat ini dengan mengganti biota tanah alami yang hilang akibat pemakaian bahan kimia, baik pupuk maupun pestisida. Pupuk hayati Biotamax $^{\mathrm{TM}}$ mampu meningkatan pertumbuhan, volume akar dan buluh-buluh akar 30-66\% .

Rukmana (2007) menyatakan bahwa pemberian kompos sebanyak 10 t.ha ${ }^{-1}$ pada tanaman tomat dapat memberikan hasil $84,84 \%$ dibanding dengan tanpa kompos hanya mencapai 4,25 t.ha ${ }^{-1}$. Hasil penelitian Sutejo (2002) menunjukkan bahwa perlaukan dosis pupuk kompos 10 t.ha $^{-1}$ mampu meningkatkan hasil segar ekonomis tanaman petsai seberat 21,30 t.ha- ${ }^{1}$, bila dibandingkan dengan tanpa kompos yang hasil segar ekonomisnya hanya 12,73 t.ha $^{-}$ 1 .

Tujuan penelitian ini adalah a) mengetahui pengaruh dosis pupuk pupuk kandang ayam pedaging terhadap pertumbuhan dan hasil tanaman petsai, b) mengetahui pengaruh frekuensi pemberian pupuk hayati Biotamax ${ }^{\mathrm{TM}}$ terhadap pertumbuhan dan hasil tanaman petsai, dan c) mengetahui interaksi dosis pupuk pupuk kandang ayam pedaging dengan frekuensi pemberian pupuk hayati Biotamax ${ }^{\mathrm{TM}}$ terhadap pertumbuhan dan hasil tanaman petsai. Hipotesis penelitian adalah a) pemberian pupuk kandang ayam pedaging dosis 15 ton.ha ${ }^{-1}$ dapat memberikan pertumbuhan dan hasil tanaman petsai terbaik; b) frekuensi pemberian pupuk hayati biotamax ${ }^{\mathrm{tm}} 7$ hari sebelum tanam dengan dosis 0,09 g.petak ${ }^{-1}$ dapat memberikan pertumbuhan dan hasil tanaman petsai terbaik; dan c) interaksi pemberian dosis pupuk kandang ayam pedaging 15 ton.ha ${ }^{-1}$ dan frekuensi pemberian pupuk hayati Biotamax ${ }^{\mathrm{tm}} 7$ hari sebelum tanam dengan dosis 0,09 g. petak $^{-1}$ dapat memberikan pertumbuhan dan hasil tanaman petsai terbaik.

\section{BAHAN DAN METODE}

Percobaan ini dilaksanakan di Desa Selat, Kabupaten Buleleng, pada bulan November - Desember 2018, ketinggian tempat 300 meter dari atas permukaan laut. Tekstur tanah tempat penelitian berdasarkan hasil analisis di Laboratorium Tanah Fakultas Pertanian UNUD Denpasar dan Kriteria penilaian sifat-sifat kimia tanah (Pusat Penelitian Tanah,1983) yaitu lempung berliat, dengan $\mathrm{pH}$ tanah netral 7,3, DHL 2,83 (sedang), C Organik 0,24\% (sangat rendah), $\mathrm{N}$ total $0,16 \%$ (sangat rendah), $\mathrm{P}$ tersedia $100,30 \mathrm{ppm}$ (sangat tinggi), $\mathrm{K}$ tersedia $647,44 \mathrm{ppm}$ (sangat tinggi). Waktu percobaan ini dilakukan 2 bulan mulai dari pengolahan tanah hingga panen berumur 40 hst.

Bahan-bahan yang dipergunakan dalam percobaan ini meliputi benih petsai jenis pak choi varitas "Emone 26". Pupuk kandang ayam pedaging, pupuk hayati Biotamax $^{\mathrm{TM}}$, pupuk Urea $(\mathrm{N})$, dan Insektisida organik. Alat yang diperlukan dalam percobaan ini meliputi cangkul, timbangan digital, timbangan analog, pisau, alat-alat tulis, oven, sekop, cangkul, sabit, bambu, meteran, cetok, traktor, 
jaring, tali rafia, palstik, gembor, selang, dan lain-lain.

Rancangan yang digunakan dalam percobaan ini adalah metode percobaan dengan Rancangan Acak Kelompok (RAK) disusun secara faktorial dengan dua faktor yang dikombinasikan. Faktor I: Perlakuan pemberian dosis pupuk kandang ayam pedaging yang terdiri dari tiga taraf, yaitu $\mathrm{A}_{0}$ : Tanpa pupuk kandang ayam pedaging, $\mathrm{A}_{1}$ : Dosis pupuk kandang ayam pedaging 15 ton.ha $^{-1}$ (3 kg.petak $\left.{ }^{-1}\right), \mathrm{A}_{2}$ : Dosis pupuk kandang ayam pedaging 30 ton.ha $^{-1}\left(6\right.$ kg.petak $\left.^{-1}\right)$. Faktor II: Frekuensi pemberian pupuk hayati BiotaMax ${ }^{\mathrm{TM}}$ terdiri dari empat taraf, yaitu; $\mathrm{B}_{0}$ : Tanpa pemberian pupuk hayati BiotaMax $^{\mathrm{TM}}$. $\mathrm{B}_{1}$ : frekuensi pemberian pupuk hayati BiotaMax ${ }^{\mathrm{TM}}$ sekaligus yaitu 7 hari sebelum tanam dengan dosis 0,09 g.petak ${ }^{-1}$. B B $_{2}$ Frekuensi pemberian pupuk hayati BiotaMax $^{\mathrm{TM}} 2$ kali yaitu 7 hari sebelum tanam dan 14 hari setelah tanam dengan dosis setiap pemberian 0,045 g.petak ${ }^{-1}$, sehingga dosis total 0,09 g.petak ${ }^{-}$ 1. $\mathrm{B}_{3}$ :Frekuensi pemberian pupuk hayati BiotaMax $^{\mathrm{TM}} 3$ kali yaitu 7 hari sebelum tanam 14 dan 28 hari setelah tanam dengan dosis setiap pemberian 0,03g. petak $^{-1}$ sehingga dosis total 0,09 g.petak ${ }^{-1}$. Dengan demikian terdapat 12 kombinasi percobaan, di mana setiap perlakukan kombinasi diulang sebanyak tiga kali, sehingga jumlah total keseluruhan unit perlakukan adalah 36 buah. Ukuran petak $2 \mathrm{~m} \times 1 \mathrm{~m}$.

Pengamatan terhadap variabel pertumbuhan dan hasil tanaman dilakukan sejak 14, 21, 28, 35, dan 40 hari setelah tanam. Variabel yang diamati adalah Tinggi tanaman $(\mathrm{cm})$, Jumlah daun per tanaman (helai), Luas daun per tanaman $\left(\mathrm{cm}^{2}\right)$, Berat basah tajuk $(\mathrm{g})$, Berat kering oven tajuk (g), Berat basah akar (g), Berat kering oven akar $(\mathrm{g})$, Berat basah total tanaman per hektar (ton.ha ${ }^{-1}$ ), Berat basah total per tanaman $(\mathrm{g})$, Berat kering oven total per tanaman $(\mathrm{g})$, rasio berat kering tajuk/akar, Diameter krop (mm), Berat ekonomis per hektar (ton.ha ${ }^{-1}$ )

\section{HASIL DAN PEMBAHASAN Hasil}

Hasil analisis ragam menunjukkan bahwa perlakuan dosis pupuk kandang ayam pedaging berpengaruh sangat nyata $(\mathrm{p}<0,01)$ terhadap berat basah tajuk, berat kering oven tajuk, berat basah akar, berat basah total per hektar, berat basah total per tanaman,berat kering oven, diameter krop, berat ekonomis per hektar, tetapi berpengaruh nyata $(p<0,05)$ terhadap luas daun pada umur $40 \mathrm{hst}$, dan berat kering oven akar, dan berpengaruh tidak nyata $(\mathrm{p} \geq 0,05)$ pada rasio berat kering tajuk/akar.

Perlakuan Frekuensi pemberian pupuk hayati BiotaMax $^{\mathrm{TM}}$ berpengaruh sangat nyata $(p<0,01)$ terhadap tinggi tanaman pada umur 14 hst, 21 hst, jumlah daun pada umur $14 \mathrm{hst}, 21 \mathrm{hst}$, luas daun umur $14 \mathrm{hst}$, tetapi berpengaruh nyata $(\mathrm{p}<0,05)$ terhadap jumlah daun pada umur 40 hst, berat kering oven tajuk, berat basah oven tajuk, berat basah total per hektar dan berat ekonimis per hektar dan berpengaruh tidak nyata $(\mathrm{p} \geq 0,05)$ pada tinggi tanaman 28 hst, 35 hst, 40 hst, jumlah daun 28 hst sampai 35 hst, luas daun 21 hst, 28 hst, 35 hst, 40 hst, berat basah akar, berat kering oven akar, berat basah total per tanaman, berat kering oven total, rasio berat kering tajuk/akar dan diameter krop.

\section{Tinggi tanaman}

Hasil analisis ragam menunjukkan bahwa perlakuan dosis pupuk kandang ayam pedaging berpengaruh sangat nyata $(\mathrm{p}<0,01)$ terhadap tinggi tanaman pada umur 14 hst, 21 hst, 28 hst, 35 hst, 40 hst (Tabel 1).

\section{Jumlah daun per tanaman}

Hasil analisis ragam menunjukkan bahwa perlakuan dosis pupuk kandang ayam pedaging berpengaruh sangat nyata $(\mathrm{p}<0,01)$ terhadap jumlah daun 14 hst, 21 hst, 28 hst, 35 hst, 40 hst (Tabel 2). 
Tabel 1. Pengaruh pemberian dosis pupuk kandang ayam pedaging dan Frekuensi pemberian pupuk hayati Biotamax ${ }^{\mathrm{TM}}$ terhadap tinggi tanaman petsai.

\begin{tabular}{|c|c|c|c|c|c|}
\hline \multirow{2}{*}{ Perlakuan } & \multicolumn{5}{|c|}{ Rerata tinggi tanaman $(\mathrm{cm})$ pada umur } \\
\hline & $14 \mathrm{hst}$ & $21 \mathrm{hst}$ & $28 \mathrm{hst}$ & $35 \mathrm{hst}$ & $40 \mathrm{hst}$ \\
\hline \multicolumn{6}{|c|}{ Pemberian dosis pupuk kandang ayam } \\
\hline Kontrol $\left(\mathrm{A}_{0}\right)$ & $13,23 \mathrm{c}$ & $20,05 \mathrm{c}$ & $24,80 \mathrm{a}$ & $26,02 \mathrm{c}$ & $27,48 b$ \\
\hline $15 \mathrm{t} / \mathrm{ha}\left(\mathrm{A}_{1}\right)$ & $14,74 \mathrm{~b}$ & $22,36 b$ & $27,68 \mathrm{a}$ & $28,73 \mathrm{~b}$ & $29,63 a$ \\
\hline $30 \mathrm{t} / \mathrm{ha}\left(\mathrm{A}_{2}\right)$ & $16,77 \mathrm{a}$ & $23,98 \mathrm{a}$ & $29,66 a$ & $30,16 \mathrm{a}$ & $31,53 \mathrm{a}$ \\
\hline BNT 5\% & 0,93 & 1,07 & - & 1,27 & 1,23 \\
\hline \multicolumn{6}{|c|}{ Frekuensi pemberian Biotamax ${ }^{\mathrm{TM}}$} \\
\hline Kontrol $\left(\mathrm{B}_{0}\right)$ & $15,27 \mathrm{ab}$ & $22,21 \mathrm{~b}$ & $26,64 a$ & $28,31 \mathrm{a}$ & $29,67 \mathrm{a}$ \\
\hline 1 kali $\left(B_{1}\right)$ & $16,01 \mathrm{a}$ & $23,47 \mathrm{a}$ & $27,77 \mathrm{a}$ & $28,87 \mathrm{a}$ & $30,00 \mathrm{a}$ \\
\hline 2 kali $\left(B_{2}\right)$ & $14,71 \mathrm{bc}$ & $22,08 \mathrm{~b}$ & $27,11 \mathrm{a}$ & $28,27 \mathrm{a}$ & $29,46 a$ \\
\hline 3 kali $\left(B_{3}\right)$ & $13,67 \mathrm{c}$ & $20,77 \mathrm{a}$ & $26,66 \mathrm{a}$ & $27,76 \mathrm{a}$ & $29,06 \mathrm{a}$ \\
\hline BNT 5\% & 1,07 & 1,23 & - & - & - \\
\hline
\end{tabular}

Keterangan: Angka-angka yang diikuti oleh huruf yang sama pada perlakuan dan variabel yang sama menunjukkan perbedaan yang tidak nyata pada uji BNT 0,05

Tabel 2. Pengaruh pemberian dosis pupuk kandang ayam pedaging dan Frekuensi pemberian pupuk hayati Biotamax ${ }^{\mathrm{TM}}$ terhadap jumlah daun tanaman petsai.

\begin{tabular}{|c|c|c|c|c|c|}
\hline \multirow{2}{*}{ Perlakuan } & \multicolumn{5}{|c|}{ Jumlah daun per tanaman (helai) pada umur : } \\
\hline & 14 & 21 & 28 & 35 & 40 \\
\hline \multicolumn{6}{|c|}{ Pemberian dosis pupuk kandang ayam } \\
\hline Kontrol $\left(\mathrm{A}_{0}\right)$ & $4,77 \mathrm{c}$ & $7,10 \mathrm{c}$ & $9,83 \mathrm{~b}$ & $11,47 \mathrm{~b}$ & $13,47 \mathrm{~b}$ \\
\hline $15 \mathrm{t} / \mathrm{ha}\left(\mathrm{A}_{1}\right)$ & $5,35 b$ & $8,25 \mathrm{~b}$ & $10,98 \mathrm{a}$ & $12,50 \mathrm{a}$ & $15,20 \mathrm{a}$ \\
\hline $30 \mathrm{t} / \mathrm{ha}\left(\mathrm{A}_{2}\right)$ & $6,03 \mathrm{a}$ & $9,20 \mathrm{a}$ & $11,45 \mathrm{a}$ & $12,82 \mathrm{a}$ & $15,83 \mathrm{a}$ \\
\hline BNT $5 \%$ & 0,35 & 0,40 & 0,80 & 0,65 & 0,72 \\
\hline \multicolumn{6}{|c|}{ Frekuensi pemberian Biotamax ${ }^{\mathrm{TM}}$} \\
\hline Kontrol $\left(\mathrm{B}_{0}\right)$ & $5,29 b$ & $8,22 \mathrm{~b}$ & $10,80 \mathrm{a}$ & $12,18 \mathrm{a}$ & $14,42 b$ \\
\hline 1 kali $\left(\mathrm{B}_{1}\right)$ & $5,89 \mathrm{a}$ & $8,84 a$ & $11,40 \mathrm{a}$ & $12,84 \mathrm{a}$ & $15,49 \mathrm{a}$ \\
\hline 2 kali $\left(B_{2}\right)$ & $5,24 b$ & $7,98 \mathrm{bc}$ & $10,62 \mathrm{a}$ & $12,22 \mathrm{a}$ & $15,07 \mathrm{ab}$ \\
\hline 3 kali $\left(B_{3}\right)$ & $5,11 b$ & $7,69 \mathrm{c}$ & $10,20 \mathrm{a}$ & $11,80 \mathrm{a}$ & $14,36 \mathrm{~b}$ \\
\hline BNT $5 \%$ & 0,40 & 0,46 & 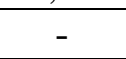 & - & 0,83 \\
\hline
\end{tabular}

Keterangan: Angka-angka yang diikuti oleh huruf yang sama pada perlakuan dan variabel yang sama menunjukkan perbedaan yang tidak nyata pada uji BNT 0,05.

Tabel 3. Pengaruh pemberian dosis pupuk kandang ayam pedaging dan Frekuensi pemberian pupuk hayati Biotamax ${ }^{\mathrm{TM}}$ terhadap luas daun tanaman petsai.

\begin{tabular}{|c|c|c|c|c|c|}
\hline \multirow{2}{*}{ Perlakuan } & \multicolumn{5}{|c|}{ Luas daun per tanaman $\left(\mathrm{cm}^{2}\right)$ pada umur } \\
\hline & 14hst & $21 \mathrm{hst}$ & $28 \mathrm{hst}$ & $35 \mathrm{hst}$ & 40 hst \\
\hline \multicolumn{6}{|c|}{ Pemberian dosis pupuk kandang ayam } \\
\hline Kontrol $\left(\mathrm{A}_{0}\right)$ & $48,00 \mathrm{c}$ & $67,77 \mathrm{c}$ & $82,65 \mathrm{c}$ & $88,05 \mathrm{c}$ & $94,97 \mathrm{~b}$ \\
\hline $15 \mathrm{t} / \mathrm{ha}\left(\mathrm{A}_{1}\right)$ & $53,67 \mathrm{~b}$ & $76,07 \mathrm{~b}$ & $97,03 \mathrm{~b}$ & $99,92 \mathrm{~b}$ & $102,88 \mathrm{~b}$ \\
\hline $30 \mathrm{t} / \mathrm{ha}\left(\mathrm{A}_{2}\right)$ & 59,67 a & $88,45 \mathrm{a}$ & $112,38 \mathrm{a}$ & $114,35 \mathrm{a}$ & $120,13 \mathrm{a}$ \\
\hline BNT 5\% & 3,94 & 6,52 & 13,24 & 16,14 & 16,02 \\
\hline \multicolumn{6}{|c|}{ Frekuensi pemberian Biotamax ${ }^{\mathrm{TM}}$} \\
\hline Kontrol $\left(\mathrm{B}_{0}\right)$ & $51,11 \mathrm{~b}$ & $74,67 \mathrm{a}$ & $97,31 \mathrm{a}$ & $95,62 \mathrm{a}$ & $98,84 \mathrm{a}$ \\
\hline 1 kali $\left(B_{1}\right)$ & $59,78 \mathrm{a}$ & $79,69 \mathrm{a}$ & $105,10 \mathrm{a}$ & $108,04 \mathrm{a}$ & $113,16 \mathrm{a}$ \\
\hline 2 kali $\left(B_{2}\right)$ & $52,67 \mathrm{~b}$ & $77,93 \mathrm{a}$ & $98,06 \mathrm{a}$ & $100,84 \mathrm{a}$ & $107,82 \mathrm{a}$ \\
\hline 3 kali $\left(B_{3}\right)$ & $51,56 \mathrm{~b}$ & $77,42 \mathrm{a}$ & $88,94 \mathrm{a}$ & $98,58 \mathrm{a}$ & $104,16 \mathrm{a}$ \\
\hline BNT 5\% & 4,55 & - & - & - & - \\
\hline
\end{tabular}


Keterangan: Angka-angka yang diikuti oleh huruf yang sama pada perlakuan dan variabel yang sama menunjukkan perbedaan yang tidak nyata pada uji BNT 0,05.

Luas daun per tanaman

Hasil analisis ragam menunjukkan bahwa perlakuan dosis pupuk kandang ayam pedaging berpengaruh sangat nyata

$(\mathrm{p}<0,01)$ terhadap luas daun $14 \mathrm{hst}, 21 \mathrm{hst}$, 28 hst, 35 hst (Tabel 3).

\section{Berat kering oven tajuk}

Tabel 4. Pengaruh pemberian dosis pupuk kandang ayam pedaging dan frekuensi pemberian pupuk hayati Biotamax ${ }^{\mathrm{TM}}$ terhadap berat kering oven akar, berat kering oven tajuk, dan berat kering oven total tanaman petsai $(\mathrm{g})$

\begin{tabular}{cccc}
\hline Perlakuan & $\begin{array}{c}\text { Berat kering oven } \\
\text { tajuk }(\mathrm{g})\end{array}$ & $\begin{array}{c}\text { Berat kering oven } \\
\text { akar }(\mathrm{g})\end{array}$ & $\begin{array}{c}\text { Berat kering oven } \\
\text { total }(\mathrm{g})\end{array}$ \\
\hline Pemberian dosis pupuk kandang ayam & & $7,92 \mathrm{~b}$ \\
\hline Kontrol $\left(\mathrm{A}_{0}\right)$ & $7,02 \mathrm{~b}$ & $0,89 \mathrm{~b}$ & $9,20 \mathrm{ab}$ \\
\hline $15 \mathrm{t} / \mathrm{ha}\left(\mathrm{A}_{1}\right)$ & $8,12 \mathrm{ab}$ & $1,17 \mathrm{ab}$ & $10,47 \mathrm{a}$ \\
\hline $30 \mathrm{t} / \mathrm{ha}\left(\mathrm{A}_{2}\right)$ & $9,26 \mathrm{a}$ & $1,22 \mathrm{a}$ & \\
\hline BNT 5\% & 1,30 & 0,28 & $8,40 \mathrm{~b}$ \\
\hline Frekuensi pemberian Biotamax & & $10,59 \mathrm{a}$ \\
\hline Kontrol $\left(\mathrm{B}_{0}\right)$ & $7,59 \mathrm{~b}$ & $1,03 \mathrm{a}$ & $9,23 \mathrm{ab}$ \\
\hline 1 kali $\left(\mathrm{B}_{1}\right)$ & $9,39 \mathrm{a}$ & $1,20 \mathrm{a}$ & $8,58 \mathrm{~b}$ \\
\hline 2 kali $\left(\mathrm{B}_{2}\right)$ & $8,14 \mathrm{ab}$ & $1,08 \mathrm{a}$ & 1,67 \\
\hline 3 kali $\left(\mathrm{B}_{3}\right)$ & $7,41 \mathrm{~b}$ & $1,06 \mathrm{a}$ & - \\
\hline BNT $5 \%$ & 1,50 & - & $\mathrm{a}$
\end{tabular}

Keterangan: Angka-angka yang diikuti oleh huruf yang sama pada perlakuan dan variabel yang sama menunjukkan perbedaan yang tidak nyata pada uji BNT 0,05

Tabel 5. Kombinasi pemberian dosis pupuk kandang ayam pedaging dan frekuensi pemberian pupuk hayati Biotamax ${ }^{\mathrm{TM}}$ terhadap berat berat kering oven total tanaman petsai $(\mathrm{g})$

\begin{tabular}{ccccccccc}
\hline PLK & $\mathrm{A}_{0}$ & \multicolumn{2}{c}{$\mathrm{A}_{1}$} & \multicolumn{2}{c}{$\mathrm{A}_{2}$} & \multicolumn{2}{c}{ Rerata B } \\
\hline $\mathrm{B}_{0}$ & 5,29 & $\mathrm{l}$ & 8,96 & $\mathrm{i}$ & 10,11 & $\mathrm{e}$ & 8,62 & $\mathrm{a}$ \\
\hline $\mathrm{B}_{1}$ & 11,06 & $\mathrm{c}$ & 10,59 & $\mathrm{~d}$ & 11,61 & $\mathrm{a}$ & 10,59 & $\mathrm{a}$ \\
\hline $\mathrm{B}_{2}$ & 7,59 & $\mathrm{k}$ & 9,02 & $\mathrm{~h}$ & 11,06 & $\mathrm{~b}$ & 9,23 & $\mathrm{a}$ \\
\hline $\mathrm{B}_{3}$ & 7,72 & $\mathrm{j}$ & 9,57 & $\mathrm{f}$ & 9,12 & $\mathrm{~g}$ & 8,80 & $\mathrm{a}$ \\
\hline & & & & & & & & \\
\hline Rerata A & 7,92 & $\mathrm{~b}$ & 9,54 & $\mathrm{a}$ & 10,47 & $\mathrm{a}$ & &
\end{tabular}

Keterangan: Angka-angka yang diikuti oleh huruf yang sama pada perlakuan dan variabel yang sama menunjukkan perbedaan yang tidak nyata pada Uji Jarak Berganda Duncan (DMRT) 0,05 . 
Tabel 6. Pengaruh dosis pupuk kandang ayam pedaging dan frekuensi pemberian pupuk hayati BiotaMax $^{\mathrm{TM}}$ terhadap basah akar, berat basah tajuk, dan berat basah total per tanaman petsai

\begin{tabular}{cccc}
\hline Perlakuan & $\begin{array}{l}\text { Berat basah akar } \\
(\mathbf{g})\end{array}$ & $\begin{array}{l}\text { Berat basah tajuk } \\
(\mathbf{g})\end{array}$ & $\begin{array}{l}\text { Berat basah total } \\
\text { per tanaman }(\mathbf{g})\end{array}$ \\
\hline Pemberian dosis pupuk kandang ayam & & \\
\hline Kontrol $\left(\mathrm{A}_{0}\right)$ & $6,64 \mathrm{c}$ & $180,24 \mathrm{~b}$ & $186,88 \mathrm{~b}$ \\
\hline 15t/ha( $\left.\mathrm{A}_{1}\right)$ & $9,21 \mathrm{~b}$ & $267,90 \mathrm{a}$ & $2775,19 \mathrm{a}$ \\
\hline $30 \mathrm{t} / \mathrm{ha}\left(\mathrm{A}_{2}\right)$ & $10,16 \mathrm{a}$ & $272,89 \mathrm{a}$ & $300,55 \mathrm{a}$ \\
\hline BNT 5\% & 1,50 & 33,41 & 32,34 \\
\hline Frekuensi pemberian Biotamax & & \\
\hline Kontrol $\left(\mathrm{B}_{0}\right)$ & $7,89 \mathrm{~b}$ & $214,67 \mathrm{~b}$ & $243,33 \mathrm{~b}$ \\
\hline 1 kali $\left(\mathrm{B}_{1}\right)$ & $9,68 \mathrm{a}$ & $275,97 \mathrm{a}$ & $285,64 \mathrm{a}$ \\
\hline 2 kali $\left(\mathrm{B}_{2}\right)$ & $8,79 \mathrm{~b}$ & $247,03 \mathrm{ab}$ & $255,82 \mathrm{ab}$ \\
\hline 3 kali $\left(\mathrm{B}_{3}\right)$ & $8,32 \mathrm{~b}$ & $223,71 \mathrm{~b}$ & $232,03 \mathrm{~b}$ \\
\hline BNT 5\% & 1,74 & 38,58 & 37,34 \\
\hline
\end{tabular}

Keterangan: Angka-angka yang diikuti oleh huruf yang sama pada perlakuan dan variabel yang sama menunjukkan perbedaan yang tidak nyata pada uji BNT 0,05

Tabel 7. Pengaruh dosis pupuk kandang ayam pedaging dan frekuensi pemberian pupuk hayati BiotaMax $^{\mathrm{TM}}$ terhadap berat basah per hektar, berat ekonomis per hektar, rasio berat kering tajuk/akar, dan diameter krop tanaman petsai.

\begin{tabular}{|c|c|c|c|c|}
\hline Perlakuan & $\begin{array}{l}\text { Berat basah total } \\
\text { per hektar } \\
\left(\text { ton.ha }^{-1}\right)\end{array}$ & $\begin{array}{l}\text { Berat ekonomis } \\
\text { per hektar } \\
\left.\text { (ton.ha }^{-1}\right)\end{array}$ & $\begin{array}{c}\text { Rasio berat } \\
\text { kering } \\
\text { tajuk/akar }\end{array}$ & $\begin{array}{c}\text { Diameter krop } \\
(\mathrm{mm})\end{array}$ \\
\hline \multicolumn{5}{|c|}{ Pemberian dosis pupuk kandang ayam } \\
\hline Kontrol $\left(\mathrm{A}_{0}\right)$ & $25,35 \mathrm{c}$ & $20,36 \mathrm{~b}$ & $8,76 \mathrm{a}$ & $60,63 \mathrm{c}$ \\
\hline $15 \mathrm{t} / \mathrm{ha}\left(\mathrm{A}_{1}\right)$ & $36,89 \mathrm{~b}$ & $29,26 \mathrm{a}$ & $8,94 a$ & $69,50 \mathrm{~b}$ \\
\hline $30 \mathrm{t} / \mathrm{ha}\left(\mathrm{A}_{2}\right)$ & $37,54 \mathrm{a}$ & $30,10 \mathrm{a}$ & $9,02 \mathrm{a}$ & $72,95 \mathrm{a}$ \\
\hline BNT 5\% & 4,06 & 2,73 & - & 5,72 \\
\hline \multicolumn{5}{|c|}{ Frekuensi pemberian Biotamax ${ }^{\mathrm{TM}}$} \\
\hline Kontrol $\left(\mathrm{B}_{0}\right)$ & $29,63 b$ & $23,55 b$ & $7,81 \mathrm{a}$ & $65,02 \mathrm{a}$ \\
\hline 1 kali $\left(B_{1}\right)$ & $35,22 \mathrm{a}$ & $28,21 \mathrm{a}$ & $9,52 \mathrm{a}$ & $71,42 \mathrm{a}$ \\
\hline 2 kali $\left(B_{2}\right)$ & $35,13 \mathrm{a}$ & $27,60 \mathrm{a}$ & $9,33 \mathrm{a}$ & $69,31 \mathrm{a}$ \\
\hline 3 kali $\left(B_{3}\right)$ & $33,51 \mathrm{a}$ & $26,91 \mathrm{a}$ & $8,99 \mathrm{a}$ & $65,02 \mathrm{a}$ \\
\hline BNT 5\% & 4,69 & 3,15 & - & - \\
\hline
\end{tabular}

Keterangan: Angka-angka yang diikuti oleh huruf yang sama pada perlakuan dan variabel yang sama menunjukkan perbedaan yang tidak nyata pada uji BNT 0,05

\section{Pembahasan}

Berdasarkan hasil perhitungan penelitian ternyata pemberian dosis pupuk kandang ayam pedaging dosis 30 ton.ha ${ }^{-1}$ $\left(\mathrm{A}_{2}\right)$ memberikan pengaruh yang sangat nyata $(\mathrm{p}<0,01)$ terhadap berat ekonomis per hektar (ton.ha ${ }^{-1}$ ) yaitu dengan berat 30,10 ton.ha ${ }^{-1}$, hal ini didukung oleh tinggi tanaman, jumlah daun, luas daun, dan berat basah tajuk yang meningkat dibandingkan dengan pemberian pupuk kandang ayam pedaging dosis 15 ton.ha ${ }^{-1}$. Terbukti dari hasil percobaan tinggi tanaman umur 14 hst sampai umur 40 hst mengalami peningkatan. Menunjukkan bahwa pemberian pupuk kandang ayam pedaging sangat bermanfaat untuk tamanan, sebagai sumber makanan tambahan baik bagi tanaman maupun tanah.

Tampak dengan jelas dari data pengamatan tinggi tanaman bahwa tinggi tanaman pada pemberian dosis pupuk kandang ayam pedaging 30 ton.ha ${ }^{-1}$ mampu memberikan pengaruh yang sangat nyata dari semua pengamatan dibandingkan pemberian pupuk kandang ayam pedaging dosis 15 ton.ha $^{-1}$. Juga 
terjadi pada pengamatan jumlah daun per tanaman bahwa jumlah daun per tanaman pada umur 14 hst sampai 40 hst berpengaruh sangat nyata terhadap jumlah daun, bisa dikatakan bahwa pemberian pupuk kandang ayam pedaging dosis 30 ton.ha $^{-1}$ sangat baik bagi tanaman. Data lebih jelas terdapat pada Tabel 1.

Pengaruh pemberian dosis pupuk kandang ayam pedaging terhadap tinggi tanaman dan jumlah daun per tanaman menunjukkan bahwa dengan dosis 30 ton.ha ${ }^{-1}$ terjadi peningkatan tinggi tanaman dan jumlah daun per tanaman yang nyata. Pengaruh pemberian dosis pupuk kandang ayam pedaging berpengaruh tidak nyata tehadap rasio berat kering tajuk/akar, tetapi berngaruh nyata terhadap berat kering oven akar, dan berpengaruh sangat nyata terhadap berat kering oven tajuk, berat kering oven total, berat basah tajuk, berat basah akar, berat basah total per hektar, berat basah total per tanaman, diameter krop dan berat ekonomis. Pada pengamatan ketiga variabel ini juga ditunjukkan bahwa dengan pemberian dosis pupuk kandang ayam pedaging 30 ton.ha ${ }^{-1}$ cenderung memberikan hasil tertinggi. Ini memberikan petunjuk bahwa pada penanaman tanaman petsai, pemberian dosis pupuk kandang ayam pedaging sangat baik bila memberikan dosis 30 ton.ha ${ }^{-1}$ atau $6 \mathrm{~kg}$.petak ${ }^{-1}$. Berat kering oven per tanaman dan berat basah total terbaik diberikan pada pemberian dosis pupuk kandang ayam pedaging dosis 30 ton.ha $^{-1}\left(\mathrm{~A}_{2}\right)$, yaitu seberat $10,47 \mathrm{~g}$ dan $300,55 \mathrm{~g}$.

Pupuk organik berperan dalam memperbaiki sifat fisik tanah, seperti struktur, konsistensi, porositas, daya mengikat air, dan menjaga ketahanan tanah terhadap erosi. Pupuk organik juga mengandung hormon pertumbuhan dari golongan auksin dan giberelin yang mampu memacu pertumbuhan sejak dari kecambah sampai berbuah (Parmila et al., 2019; Purba et al., 2019). Pupuk organik dengan bahan organik merupakan salah satu pembentuk agregat tanah yang mempunyai peran sebagai bahan perekat antar partikel tanah. Komponen asam humat dan asam fulvat sebagai sementasi partikel tanah membentuk logam-humus. Pada tanah pasir pupuk organik mampu berperan sebagai pembentuk struktur tanah dari bentuk tunggal ke gumpal yang bermanfaat untuk mencegah porositas tinggi. Pupuk organik juga mempunyai manfaat dalam memberikan media bagi kehidupan mikroorganisme menguntungkan bagi kesuburan tanah dan mengurangi porostias pada tanah pasir dan membantu aerasi pada tanah lempung (Purba, J.H.; Parmila, I P.; Sari, 2018). Dalam pupuk hayati terdapat berbagai bakteri-baik seperti Rhizobium, Azospirillum, Azotobacter, Pseudomonas, Bacillus, dan bakteri pelarut fosfat. Selain bisa menambat nitrogen, bakteri Azospirillum juga dapat menghasilkan fitohormon atau zat perangsang tumbuh seperti sitokinin, auksin, giberelin, asam absisat, asam traumalin, dan etilena (Utama, 2011). Atonik atau sodium nitrophenolate dapat merangsang pertumbuhan tanaman, termasuk mempersingkat dormansi biji ulin (Purba et al., 2019) dan biji jati (Srilaba, Purba, Arsana, 2018).

Hubungan antara pemberian dosis pupuk kandang ayam pedaging dan berat ekonomis per hektar menunjukan hubungan linier, yaitu $\mathrm{y}=0,3247 \mathrm{x}+$ $21,699\left(\mathrm{R}^{2}=59,88 \%\right)$, dimana jika dosis pupuk kandang ayam pedaging ditingkatkan kemungkinan bisa memberikan peningkatan pertumbuhan dan hasil tanaman petsai. Maka dari itu perlu dikaji kembali dosi pupuk kandang ayam pedaging untuk mendapatkan hasil yang paling terbaik.

Hasil analisis regesi hubungan antara dosis pupuk kandang ayam pedaging dan berat kering oven tajuk per tanaman menunjukan hubungan linier, yaitu $\mathrm{y}=0,0608 \mathrm{x}+7,2483$, dengan $\mathrm{R}^{2}=$ $32,52 \%$. Hasil regesi menunjukkan bahwa dengan dosis pupuk kandang ayam pedaging 30 ton.ha $^{-1}$ mendapatkan hasil 
tertinggi pada perlakuan berat kering tajuk per tanaman yaitu sebesar 9,26 g atau secara nyata lebih besar $24,19 \%$ dari beratk kering oven tajuk tanpa perlakuan yaitu sebesar 7,02 g. Hasil analisis regresi yang menunjukkan linier berarti, masih ada kemungkinan peningkatan hasil berat kering oven tajuk dengan pemberian dosis yang lebih tinggi (Gambar 2)

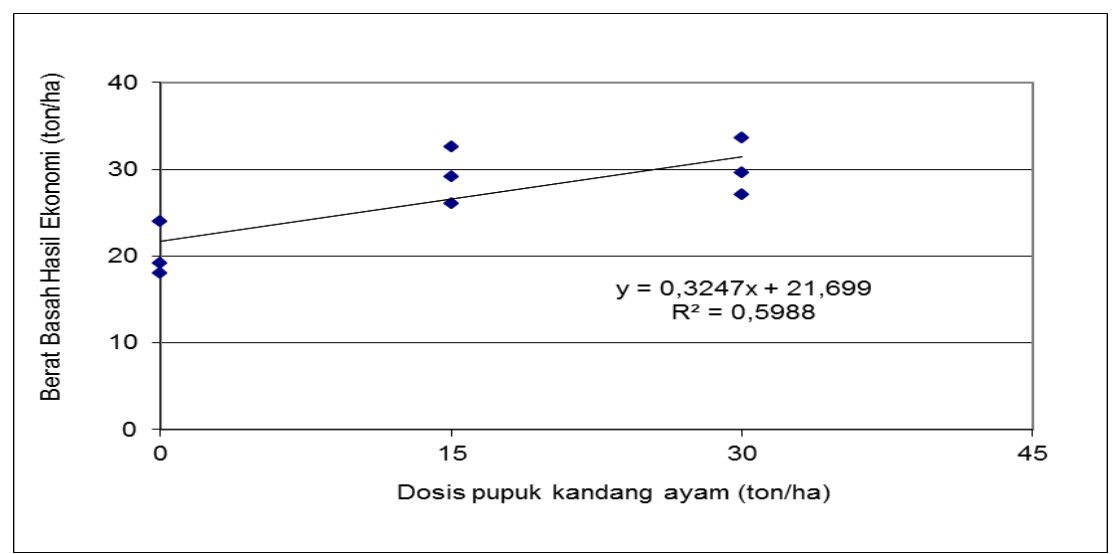

Gambar 1. Hubungan antara dosis pupuk kandang ayam pedaging dengan berat hasil ekonomis per hektar.

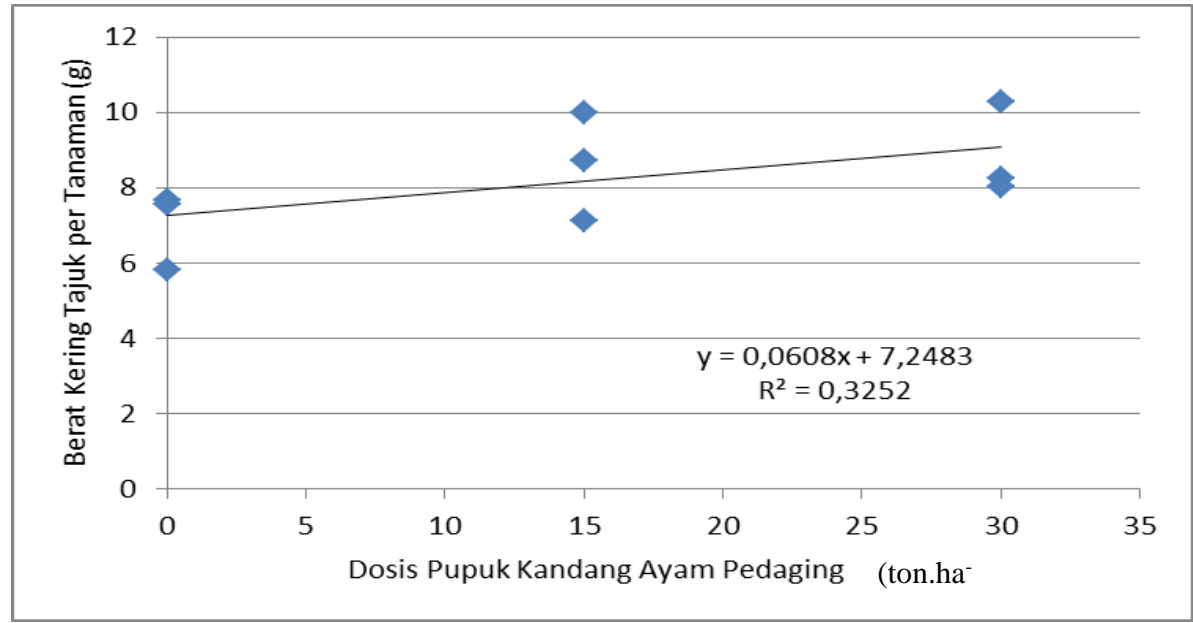

Gambar 2. Bentuk hubungan antara dosis pupuk kandang ayam pedaging dengan berat kering oven tajuk per tanaman

Hasil pengamatan menunjukkan bahwa pemberian dosis pupuk kandang ayam pedaging berpengaruh sangat nyata terhadap berat basah tajuk per tanaman. Hasil analisis regesi hubungan antara pemberian pupuk kandang ayam pedaging dan berat basah tajuk per tanaman menunjukan hubungan linier. Adapun persamaan nya adalah sebagai berikut $\mathrm{Y}=$ $3,0883 x+194,02$ dengan $\mathrm{R}^{2}=60,13 \%$.

Formula ini menunjukkan bahwa kemungkinan masih ada peningkatan dengan pemberian dosis pupuk kandang ayam pedaging yang lebih tinggi.
Tanaman dalam hal ini membutuhkan jumlah pupuk yang cukup untuk dapat tumbuh dan berproduksi optimal. Kekurangan pupuk ataupun kelebihan pupuk dapat menggangu pertumbuhan dan menurunkan hasil produksi suatu tanaman. Pengelolaan sumber daya alam yang efisien dan efektif dapat dicapai bila kebutuhan pupuk tanaman dapat diketahui secara pasti. Selain penggunaan pupuk yang tepat dan efisein, pengolahan tanah yang baik juga mempengaruhi hasil produksi suatu tanaman. Dengan demikian pupuk dapat diberikan dalam jumlah dan dosis yang tepat selama masa pertumbuhan 
dan perkembangan tanaman (Sutedjo,

2002).

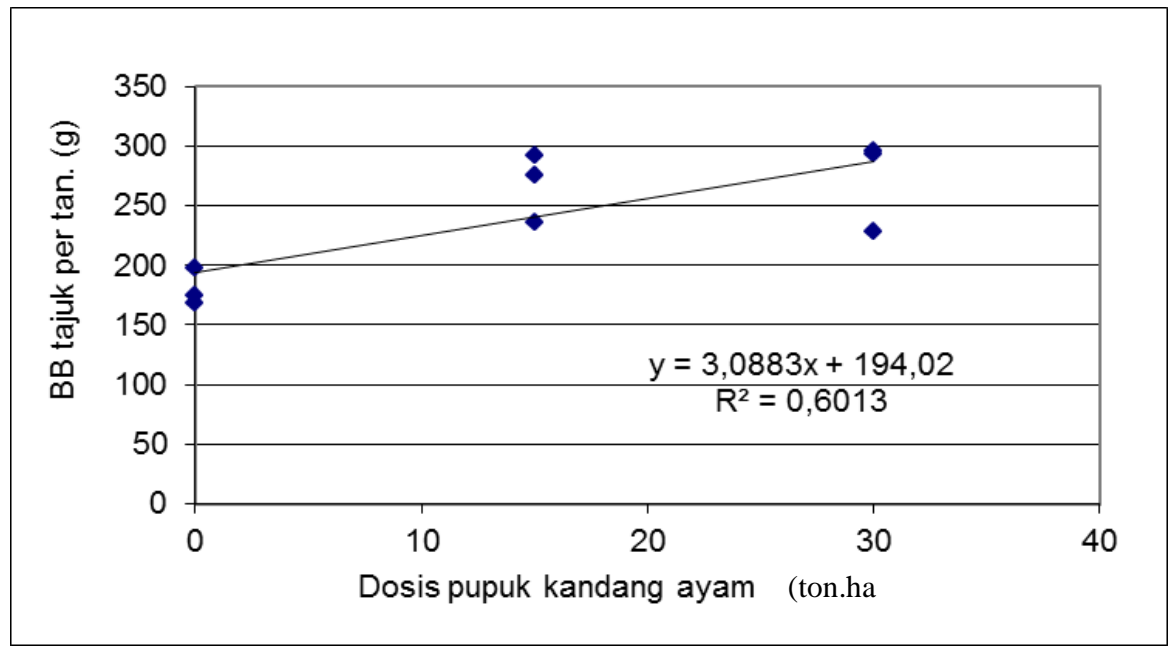

Gambar 3. Bentuk hubungan antara dosis pupuk kandang ayam pedaging dengan berat basah tajuk per tanaman

\section{Pengaruh frekuensi pemberian pupuk hayati Biotamax $^{\mathrm{TM}}$.}

Hasil penelitian menunjukkan bahwa frekuensi pemberian pupuk hayati BiotaMax $^{\mathrm{TM}}$ sekaligus yaitu 7 hari sebelum tanam dengan dosis 0,09 g.petak ${ }^{-1}$ $\left(B_{1}\right)$ memberikan berat basah tajuk tertinggi 275,97 $\mathrm{g}$ atau lebih tinggi 22,21\% bila dibandingkan dengan berat basah tajuk terendah pada kontrol $\left(\mathrm{B}_{0}\right)$, yaitu sebesar 214,67 g (tabel 6), begitu juga berat kering oven tajuk tertinggi yang di berikan dari perlakuan frekuensi pemberian pupuk hayati BiotaMax ${ }^{\mathrm{TM}}$ sekaligus yaitu 7 hari sebelum tanam dengan dosis $0,09 \quad$ g.petak ${ }^{-1} \quad\left(B_{1}\right)$ memberikan berat $9,39 \mathrm{~g}$ atau lebih tinggi $19,16 \%$ bila dibandingkan dengan berat kering oven tajuk terendah dengan tanpa perlakuan/kontrol $\left(\mathrm{B}_{0}\right)$, yaitu sebesar 7,59 g (Tabel 5). Frekuensi pemberian pupuk hayati BiotaMax $^{\mathrm{TM}}$ memberikan berat ekonomis per hektar terberat, yaitu 28,21 ton.ha ${ }^{-1}$ pada pemberian pupuk hayati Biotamax $^{\mathrm{TM}}$ sekaligus yaitu 7 hari sebelum tanam dengan dosis 0,09 g.petak ${ }^{-1}\left(\mathrm{~B}_{1}\right)$, atau secara nyata lebih berat dibandingkan dengan berat ekonomis per hektar dengan tanpa pemberian pupuk hayati BiotaMax $^{\mathrm{TM}}$. Pemberian pupuk hayati BiotaMax $^{\mathrm{TM}}$ paling baik di berikan sebelum penanaman, diduga mikoorganisme yang terkandung didalam pupuk hayati BiotaMax ${ }^{\mathrm{TM}}$ lebih awal melakukan proses dekomposisi pada tanah, sehingga ketersediaan unsur hara dalam tanah cukup memadai untuk melakukan proses pertumbuhan yang lebih baik.

Hasil ini menunjukkan bahwa frekuensi pemberian pupuk hayati BiotaMax $^{\mathrm{TM}}$ diawal merupakan pemberian terbaik dari semua perlakuan yang sudah dijelaskan. Hal ini diduga karena mikroorganisme yang terkandung dalam pupuk hayati BiotaMax $^{\mathrm{TM}}$ lebih awal melakukan proses dekomposisi terhadap pupuk organik dan tanah, sehingga unsur hara lebih cepat diserap oleh tanaman. Dan juga diduga karena jumlah dosis yang penuh diberikan diawal sehingga mikroorganisme yang ada pada pupuk hayati BiotaMax ${ }^{\mathrm{TM}}$ dapat mendekomposisi pupuk kandang ayam pedaging dan tanah dengan baik. Berpengaruhnya frekuensi pemberian pupuk hayati BiotaMax $^{\mathrm{TM}}$ terhadap berat basah tajuk per tanaman erat kaitannya dengan jumlah daun per tanaman. Berpengaruhnya frekuensi pemberian pupuk hayati BiotaMax $^{\mathrm{TM}}$ terhadap hasil-hasil tanaman petsai kemungkinan disebabkan oleh pupuk hayati BiotaMax $^{\mathrm{TM}}$ sebagai salah satu 
pupuk hayati yang dapat meningkatkan unsur hara dan biologi tanah, antara lain meningkatkan jumlah mikroorganisme tanah, unsur hara tanah, memantapkan struktur tanah, dan menambah unsur hara makro maupun mikro pada tanah.

\section{Pengaruh Interaksi antara Pemberian Dosis Pupuk Kandang Ayam Pedaging dan Frekuensi Pemberian Pupuk Hayati Biotamax $^{\mathrm{TM}}$.}

Interaksi antara dosis pupuk kandang ayam pedaging dan frekuensi pemberian pupuk hayati BiotaMax $^{\mathrm{TM}}$, berpengaruh sangat nyata $(\mathrm{p}<0,01)$ pada tinggi tanaman $14 \mathrm{hst}, 21 \mathrm{hst}$, jumlah daun 14 hst, 21 hst, 35 hst, 40 hst, luas daun umur $14 \mathrm{hst}$, dan berat basah total per tanaman, dan berpengaruh nyata $(\mathrm{p}<0,05)$ terhadap jumlah daun $28 \mathrm{hst}$, dan berat kering oven total, tetapi berpengaruh tidak nyata $(\mathrm{p} \geq 0,05)$ terhadap tingi tanaman 28 hst, 35 hst, 40 hst, luas daun 21 hst, 28 hst, 35 hst, 40 hst, berat kering oven tajuk, berat basah akar, berat basah tajuk, berat kering oven akar, berat basah total per hektar, rasio berat kering tajuk/akar, diameter krop, berat ekonomis per hektar.

Berdasarkan tabel kombinasi antara pemberian dosis pupuk kandang ayam pedaging dengan frekuensi pemberian pupuk hayati BiotaMax $^{\mathrm{TM}}$ diperoleh kombinasi perlakuan yang terbaik dilihat dari perlakuan yang nyata dan sangat nyata. Perlakuan variabel yang dilihat adalah berat kering oven total yang menunjukkan hasil interaksi nyata, jumlah daun pada pengamatan 40 hst dan berat basah total per tanaman yang menunjukkan interaksi sangat nyata (Tabel 1), dari variabel tersebut diperoleh kombinasi perlakuan yang terbaik adalah $\mathrm{A}_{2} \mathrm{~B}_{1}$, yaitu kombinasi pemberian dosis pupuk kandang ayam pedaging 30 ton.ha ${ }^{-1}$ dan frekuensi pemberian pupuk hayati BiotaMax $^{\mathrm{TM}}$ sekaligus yaitu 7 hari sebelum tanam dengan dosis 0,09 g.petak ${ }^{-1}$ dengan berat kering oven total 11,61 g, dan berat basah total per tanaman 344,82 g. (Tabel 6 dan 8).
Hal ini berarti pemberian pupuk kandang ayam pedaging secara merata dapat meningkatkan petumbuhan dan hasil tanaman petsai melihat dari tabel signifikansi yang menunjukkan hampir semua variabel perlakuan menunjukkan hubungan nyata sampai sangat nyata. Perlakuan pemberian pupuk kandang ayam pedaging dan frekewensi pemberian pupuk hayati Biotamax ${ }^{\mathrm{TM}}$ belum secara maksimal berpengaruh terhadap pertumbuhan dan hasil tanaman petsai. Interaksi antara dosis pupuk kandang ayam pedaging dan frekuensi pemberian pupuk hayati BiotaMax $^{\mathrm{TM}}$ yang tidak nyata ini dapat disebabkan oleh beberapa kemungkinan, diantaranya adalah diduga dosis pupuk kandang ayam pedaging yang belum tepat pada pengkombinasian antara pemberian dengan dosis pupuk kandang ayam pedaging dan frekuensi pemberian pupuk hayati BiotaMax $^{\mathrm{TM}}$ belum sesuai pada perlakuan dosis pupuk kandang ayam pedaging, atau dapat diduga disebabkan oleh masih kurangnya jumlah dosis pupuk hayati BiotaMax ${ }^{\mathrm{TM}}$ yang diberikan pada setiap perlakuan per tanaman petsai.

\section{SIMPULAN}

Simpulan yang dapat disampaikan dari hasil penelitian ini adalah:

1. Perlakuan pemberian dosis pupuk kandang ayam pedaging berpengaruh sangat nyata terhadap pertumbuhan dan hasil tamanan petsai (Brassica chinensis L.) Dosis pupuk kandang ayam pedaging yang terbaik adalah 30 ton. $\mathrm{h}^{-1}\left(\mathrm{~A}_{2}\right)$ yang menghasilkan berat basah hasil ekonomis per hektar yaitu sebesar 30,10 ton.ha ${ }^{-1}$. Hasil analisis regresi pengaruh pemberian pupuk kandang ayam pedaging terhadap berat hasil ekonomi mununjukkan pengaruh bersifat linier, dengan persamaan $\mathrm{y}=$ $0,3247 x+21,699$, dengan $R^{2}=$ $59,88 \%$.

2. Perlakuan frekuensi pemberian pupuk hayati BiotaMax ${ }^{\mathrm{TM}}$ berpengaruh nyata terhadap pertumbuhan dan hasil tanaman petsai (Brassica chinensis L.) 
Frekuensi pemberian pupuk hayati BiotaMax $^{\mathrm{TM}}$ yang terbaik adalah sekaligus yaitu 7 hari sebelum tanam dengan dosis 0,09 g.petak ${ }^{-1}$ yang menghasilkan berat basah hasil ekonomis per hektar yaitu sebesar 28,21 ton.ha ${ }^{-1}$.

3. Kombinasi perlakuan pemberian dosis pupuk kandang ayam pedaging dan perlakuan frekuensi pemberian pupuk hayati BiotaMax ${ }^{\mathrm{TM}}$ berpengaruh nyata terhadap berat kering oven total. Kombinasi perlakuan terbaik diberikan pada perlakuan pemberian pupuk kandang ayam pedaging dosis 30 ton.ha ${ }^{-1}$ dengan frekuensi pemberian pupuk hayati BiotaMax $^{\mathrm{TM}}$ sekaligus yaitu 7 hari sebelum tanam dengan dosis 0,09 g.petak ${ }^{-1}\left(\mathrm{~A}_{2} \mathrm{~B}_{1}\right)$, dengan berat kering oven total terberat 11,61g.

\section{DAFTAR PUSTAKA}

Hadisuwito, S. 2007. Membuat Pupuk Kompos Cair. Agromedia. Jakarta. Hal : 10.

Hanafiah, K. A. 1989. Pengaruh Pupuk Kandang dan Kapur terhadap Agihan dan Bentuk Ketersediaan P pada Tanah Latosol. Tesis S2 Bidang Kimia dan Kesuburan Tanah. PS Ilmu Tanah, PPS-UGM, Yogyakarta.

Irvan, Arif. 2007. Pengaruh Pemberian Pupuk SP-36, Kcl, Keiserit, dan Kotoran Sapi terhadap Jumlah Mikroorganisme Pada Andisol Tongkoh Kabupaten Karo. Departemen Ilmu Tanah. USU. Medan.

Laboratorium Tanah Universitas Udayana, 2018. Hasil Analisis Tanah Lokasi Penelitian.

Mayadewi, Ari. 2007. Pengaruh Jenis Pupuk Kandang dan Jenis Tanam terhadap Pertumbuhan Gulma Hasil Jagung Manis. Agritrop. 26(4) : 153-159 ISN :0215 8620.

Parmila, P., Purba, J. H., \& Suprami, L. (2019). Pengaruh Dosis Petroganik dan Kalium terhadap Pertumbuhan dan Hasil Semangka (Citrulus vulgaris SCARD). Agro Bali: Agricultural Journal, 2(1), 37-45.

Purba, J.H.; Parmila, I P.; Sari, K. K. (2018). Pengaruh Pupuk Kandang Sapi dan Jarak Tanam terhadap Pertumbuhan dan Hasil Kedelai (Glycine max L. Merrill) Varietas Edamame. Agro Bali: Agricultural Journal, 1(2), 69-81.

Purba, J. H., Sasmita, N., Komara, L. L., \& Nesimnasi, N. (2019). Comparison of seed dormancy breaking of Eusideroxylon zwageri from Bali and Kalimantan soaked with sodium nitrophenolate growth regulator. Nusantara Bioscience, 11(2), 146152.

https://doi.org/10.13057/nusbiosci/n 110206

Rukmana, R. 2007. Bertanam Petsai dan Sawi. Kanisius. Yogyakarta. Hal: 11-35.

Srilaba, N, Purba, J.H., dan Arsana, I K.N., 2018. Pengaruh Lama Perendaman dan Konsentrasi Atonik terhadap Perkecambahan Benih Jati (Tectona Grandis L.). Agro Bali: Agricultural Journal, 1(2), 108-119

Sutanto, R. 2002. Penerapan Pertanian Organik. Pemasyarakatan dan Pengembangannya. Penerbit : Kanisius, anggota IKAPI Yogyakarta.

Sutejo, M. 2002. Pupuk dan Cara Pemupukan. Renika Cipta. Jakarta.

Usman. 2012. Teknik Penepatan Nitrogen Total pada Contoh Tanah Secara Destilasi Tritimetri dan Kolorimetri Menggunakan Autoanalyzer. Buletin Teknik Pertanian. Vol 17, No 1, 2012;41:44.

Utama, S. 2011. Multifungsi Pupuk Organik, Hayati dan ZPT. http://www.agrinaonline.com/detailberita/2011/02/28/23/2867/multifu ngsi-pupuk-organik-hayati-dan-zpt. Diakses pada 16 Mei 2018. 